\title{
Establishment and characterisation of a monoclonal antibody to inhibit adhesion of Helicobacter pylori to gastric epithelial cells
}

\author{
TAKAKO OSAKI, HIROYUKI YAMAGUCHI*, HARUHIKO TAGUCHI*, MINORU FUKUDA广,

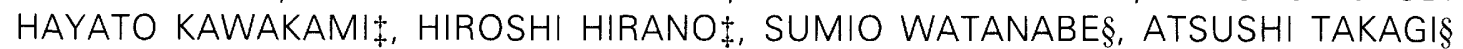 \\ and SHIGERU KAMIYA*
}

Division of Flow Cytometry, ${ }^{*}$ Department of Microbiology, + Laboratory for Electron Microscopy, $¥ 2 n d$ Department of Anatomy, Kyorin University School of Medicine, Shinkawa, Mitaka, Tokyo, Japan 181 and §Department of Internal Medicine 6. School of Medicine, Tokai University, Bohseidai, Isehara, Japan 259-11

\begin{abstract}
Monoclonal antibodies (MAbs) that inhibit adhesion of Helicobacter pylori to human gastric cancer (MKN45) cells were established to clarify the mechanism of adhesion of H. pylori. Of 53 hybridoma clones screened by the primary inhibition assay for adhesion, MAb A20 of IgM class was selected on the basis of both its reactivity to whole cells of $H$. pylori by ELISA and its inhibitory effect on adhesion of $H$. pylori. The adhesion of $H$. pylori strain TK1029 to MKN45 cells was inhibited by MAb A20, depending on the concentration of the MAb. The MAb recognised the surface antigen, lipopolysaccharide (LPS) of $\boldsymbol{H}$. pylori, suggesting that LPS is associated with adhesion of $H$. pylori to human gastric epithelial cells.
\end{abstract}

\section{Introduction}

Helicobacter pylori is a causative agent of active chronic gastritis and gastro-duodenal ulcer, and may be associated with gastric cancer and lymphoma [1-4]. The micro-organism has been shown to colonise gastric mucus and to attach to mucosal epithelial cells by histological technique [5] and by electron microscopy. Adhesion of bacteria to mucosal surfaces is essential for colonisation and subsequent pathogenesis. The bacterial adhesion factors, which include flagella, capsules, glycocalyces and lipopolysaccharides (LPS), are also important as virulence factors. $H$. pylori has a strong ability to adhere in various in-vitro test systems [6-10]. Various binding specificities and putative adhesins of $H$. pylori have been reported: an N-acetylneuraminyllactose (NAML)-binding fibrillar haemagglutinin [11], haemagglutination activities with strain specificity $[12,13]$, adhesin binding to $\mathrm{GM}_{3}$ ganglioside and sulphatides $[14,15]$ and laminin-binding protein $[16,17]$. Similarly, various types of receptor for $H$. pylori have been reported, e.g., phosphatidyl-ethanolamine $[18,19]$ and Lewis ${ }^{b}$ blood group antigen [20]. NAML-binding fibrillar haemagglutinin is now known to be an intracellular lipoprotein and the adhesin recognising phosphatidyl-ethanolamine is the catalase

Received 7 Aug. 1997; revised version accepted 9 Oct. 1997 Corresponding author: Dr T. Osaki. of $H$. pylori. However, it is not known whether a $H$. pylori-specific adhesin is involved in adhesion to epithelial cells. These adhesion properties alone may not explain tissue adhesion of $H$. pylori.

In the present study, to clarify the mechanism by which $H$. pylori adheres to gastric epithelial cells, establishment of a monoclonal antibody (MAb) to inhibit adhesion of $H$. pylori to human gastric epithelial cells was attempted.

\section{Materials and methods}

\section{Bacterial strains and culture condition}

H. pylori strain TK1029 used for immunisation of mice was isolated from gastric biopsy material from a patient with gastric ulcer. Other $H$. pylori strains were isolated from gastric biopsy materials. H. pylori NCTC11638 and H. mustelae NCTC12032 strains were kindly provided by Dr T. Ito (Tokyo Metropolitan Research Laboratory of Public Health, Japan). Helicobacter strains were cultured in Brain Heart Infusion (BHI) Agar (Difco) with horse blood $7 \%$ in an atmosphere of $\mathrm{O}_{2} 5 \%, \mathrm{CO}_{2} 10 \%, \mathrm{~N}_{2} 85 \%$ for 4 days at $37^{\circ} \mathrm{C}$. Campylobacter jejuni, Escherichia coli, Klebsiella pneumoniae, Proteus mirabilis, Pseudomonas aeruginosa, Serratia marcescens, Shigella sonnei and Vibrio cholerae were laboratory strains from the Department of Microbiology, Kyorin University School 
of Medicine. These bacteria were cultured in BHI agar at $37^{\circ} \mathrm{C}$ under aerobic or micro-aerobic conditions.

\section{Cell line}

Human gastric carcinoma cells, MKN45 and Kato III, were obtained from the Japanese Cancer Research Resources Bank. The human intestinal cell line, Intestine (Int)-407 was also used. For the adhesion assay, cells were grown at $37^{\circ} \mathrm{C}$ in RPMI-1640 (Gibco BRL, Gaithersburg, USA) containing fetal calf serum (FCS) $10 \%$ and harvested from a flask by scraping with a sterile cell scraper.

\section{H. pylori inhibition of adhesion assay}

The inhibition of adhesion of $H$. pylori to epithelial cells by MAb was tested by the following two methods. As a screening test, a qualitative method based upon urease activity of $H$. pylori was used. MKN 45 cells $\left(5 \times 10^{4}\right.$ cells $)$ were cultured in a 96-well plate coated with poly-L-Lysin (Sumitomo Bakelite Co. Ltd, Tokyo, Japan) $1 \%$ for 2 days. The monolayer MKN45 cells were washed once with RPMI-1640 containing FCS $10 \%$, and the medium was aspirated completely. Culture supernates $(50 \mu \mathrm{l})$ of hybridoma cells (MAb) and $5 \times 10^{6} \mathrm{cfu}$ of $H$. pylori in $50 \mu \mathrm{l}$ of RPMI-1640 were added to each well. After incubation for $30 \mathrm{~min}$, the culture medium was aspirated from each well. The cells in the plate were washed twice with RPMI-1640, and $100 \mu \mathrm{l}$ of urea broth medium (Difco) were added. After 1 or $2 \mathrm{~h}$, the plates were examined for a change in colour of the medium. Red colour showed the presence of adherent $H$. pylori, whereas no change in the colour of the medium showed the inhibition of adhesion of $H$. pylori to MKN45 cells by the MAb.

To confirm the inhibitory effect of MAb, the adhesion of $H$. pylori was assessed by flow cytometry [21-24]. H. pylori $\left(5 \times 10^{8} \mathrm{cfu}\right)$, labelled at room temperature for 15 min with $4 \mu \mathrm{M}$ lipophilic dye, PKH-2 (Zynaxis Cell Sciences, Phoenixville, PA, USA), were incubated with $\mathrm{MAb}$ A20 for $20 \mathrm{~min}$ at $4^{\circ} \mathrm{C}$ and washed twice with Hanks's Balanced Salts Solution containing gelatin $0.1 \%$ (HGS). MKN45, Kato III and Int-407 cells $\left(c .1 \times 10^{6}\right.$ cells) were washed once with HGS and resuspended in $500 \mu \mathrm{l}$ of HGS. $H$. pylori were also resuspended in $500 \mu \mathrm{l}$ of HGS and co-incubated with the cells for $1 \mathrm{~h}$ at $25^{\circ} \mathrm{C}$. After incubation, the cells were washed once with PBS containing sucrose $15 \%$ and then washed twice with HGS. Fluorescence intensity of the cells was analysed by flow cytometry with a 530-nm filter (FACS Vantage, Beckton Dickinson Immunocytometry Systems, San Jose, CA, USA). Fluorescence data were obtained in a logarithmic mode on a 1024 channel scale.

\section{MAb production}

MAbs were prepared by the method described by
Yamaguchi et al. [25]. BALB/c mice were immunised with sonicated whole-cell antigen of $H$. pylori strain TK1029 and boosted three times. Hybridoma cells secreting a MAb were tested by ELISA with whole-cell sonicate and cell surface antigen of $H$. pylori, and the inhibition of adhesion assay, by assessment of urease activity of $H$. pylori, was performed. BALB/c mice, pretreated with pristane 4 days before inoculation, were inoculated intraperitoneally with cloned hybridoma cells secreting a MAb. The immunoglobulin of the ascites fluid obtained from the mice was purified with an Immunoglobulin-E-Z-Separation kit (Pharmacia Biotech Co., Tokyo, Japan).

\section{ELISA}

Microtitration plates (Greiner Labortechnik Japan, Tokyo, Japan) were coated at $4^{\circ} \mathrm{C}$ for $18 \mathrm{~h}$ with sonicated antigen $(100 \mu \mathrm{g} / \mathrm{ml})$ of $H$. pylori. After washing with PBS, the plate was incubated with PBS containing skim milk (Yukijirushi Nyugyo Co., Tokyo, Japan) $1 \%$ (PBS-S) for $1 \mathrm{~h}$ at room temperature. After washing with PBS, the plate was incubated with MAbs for $1 \mathrm{~h}$ at room temperature. The bound MAbs were detected with an affinity-purified goat anti-mouse IgG and IgM horseradish peroxidase conjugate (Biosource International, Camarillo, CA, USA) diluted 1 in 5000 with PBS-S. Then, the plates were developed with OPD buffer $(0.1 \mathrm{M}$ citric acid, $0.07 \mathrm{M}$ sodium phosphate dibasic, $\mathrm{H}_{2} \mathrm{O}_{2} \quad 0.015 \%$ ) containing $o$-phenylenediamine $0.1 \%$. After reaction at room temperature for $5 \mathrm{~min}$, the developed colour was measured at $490 \mathrm{~nm}$.

The whole-cell ELISA method was used [26] for the assay of reactivity to surface antigen of $H$. pylori. Microtitration plates were coated with $100 \mu \mathrm{l}$ of a suspension of bacterial cells $\left(8 \times 10^{7} \mathrm{cfu} / \mathrm{ml}\right)$ in $\mathrm{Na}_{2} \mathrm{CO}_{3} \quad 0.38 \%$ solution containing methylglioxal (Sigma) $0.3 \% \mathrm{v} / \mathrm{v}$ and incubated overnight at $4^{\circ} \mathrm{C}$. The incubation steps and development were performed by the method described above.

\section{Immuno-electron microscopy}

The post-embedding labelling on ultra-thin sections were performed by the method described by Taguchi et al. [27]. H. pylori strain TK1029 was cultured on BHI agar containing horse blood $7 \%$ under micro-aerobic conditions for 3 days. The micro-organisms were washed with PBS and fixed with glutaraldehyde 2\% in PBS for $2 \mathrm{~h}$ at room temperature. The cell pellet was dehydrated in a graded series of dimethylformamide at $4^{\circ} \mathrm{C}$ and embedded in Lowicryl K4M (Chemische Werke Lowi GmbH, Waldkaraiburg, Germany). After infiltration with Lowicryl K4M, UV polymerisation was performed for $24 \mathrm{~h}$ at $4^{\circ} \mathrm{C}$. Ultra-thin sections were cut with glass knives and mounted on 400-mesh nickel grids. The grid was floated on a drop of PBS containing bovine serum albumin (BSA) $1 \%$ for $10 \mathrm{~min}$ and incubated with one drop of PBS containing 
goat serum $5 \%$ for $10 \mathrm{~min}$. The grid was washed with PBS and then incubated with one drop of PBS containing the diluted MAb A20 $(10 \mu \mathrm{g} / \mathrm{ml})$ in BSAPBS $0.1 \%$ for $1 \mathrm{~h}$ at room temperature. Then the grid was washed and floated on a drop of PBS containing a 1 in 50 dilution of $12 \mathrm{~nm}$ diameter colloidal gold particles-affinipure goat anti-mouse IgG + IgM (Jackson Immuno Research Laboratories, Inc. West Grove, PA, USA). After incubation at room temperature for $1 \mathrm{~h}$, the unbound colloidal gold particles were removed by floating the grid on three drops of PBS. The sections were stained with a saturated aqueous solution of uranyl acetate for $30 \mathrm{~s}$ and with lead citrate solution for $1 \mathrm{~min}$. The specimens were observed with a JEM-100 electron microscope (JEOL, Tokyo, Japan).

\section{SDS-PAGE and immunoblotting}

SDS-PAGE with acrylamide 10 or $15 \% \mathrm{w} / \mathrm{v}$ was performed by the method of Laemmli [28]. Protein or LPS was stained with a silver stain kit (BioRad Laboratories, Hercules, CA, USA). Separated proteins were transferred from the polyacrylamide gel to a nitrocellulose membrane (Schleicher and Schuell, Dassel, Germany). Electroblotting was performed in a semi-dry transblot apparatus (Millipore Corporation, Bedford, MA, USA) at $10 \mathrm{~V}$ for $45 \mathrm{~min}$. After blocking with PBS-S, the membranes were incubated at room temperature for $30 \mathrm{~min}$ with MAb $(10 \mu \mathrm{g} / \mathrm{ml})$ in PBS$\mathrm{S}$ and then at room temperature for $30 \mathrm{~min}$ with goat anti-mouse IgG and IgM conjugated with horseradish peroxidase (Biosource International) diluted 1 in 1000 with PBS-S. Immunoblots were developed with $50 \mathrm{mM}$ Tris saline containing $\mathrm{H}_{2} \mathrm{O}_{2} \quad 0.12 \%$ and $1 \mathrm{mM} \mathrm{o-}$ diaminobenzidine.

\section{Detection of glycochain after Western blotting}

SDS-PAGE and transblotting were performed as described above. The membrane was treated with GP-sensor kit (Honen Corporation, Tokyo, Japan). After incubation with avidine conjugated with horseradish peroxidase at room temperature for $20 \mathrm{~min}$, blots were developed as described above.

\section{LPS preparation}

LPS was prepared from whole cells by the hot-phenolwater technique [29]. The LPS preparations were purified by treatment with RNAase (Sigma) $50 \mu \mathrm{g} / \mathrm{ml}$ and DNAase I (Sigma) $16 \mu \mathrm{g} / \mathrm{ml}$, followed by dialysis against $50 \mathrm{mM}$ Tris buffer and centrifugation at $20000 \mathrm{~g}$ for $30 \mathrm{~min}$. The resulting suspension was freeze-dried.

\section{Results}

\section{Selection of MAbs against $H$. pylori antigen}

Culture supernates of hybridomas (862 clones) were screened for the production of antibodies to whole-cell sonicate by ELISA, and to surface antigen of $H$. pylori strain TK1029 by whole-cell ELISA. In addition, the inhibitory activity of MAbs for adhesion of $H$. pylori strain TK1029 to MKN45 cells was evaluated by qualitative adhesion assay based upon the urease activity of $H$. pylori (Fig. 1). The numbers of positive clones for ELISA, whole-cell ELISA and inhibition of adhesion assay were 251,356 and 82, respectively. A total of 53 clones was selected by these criteria.

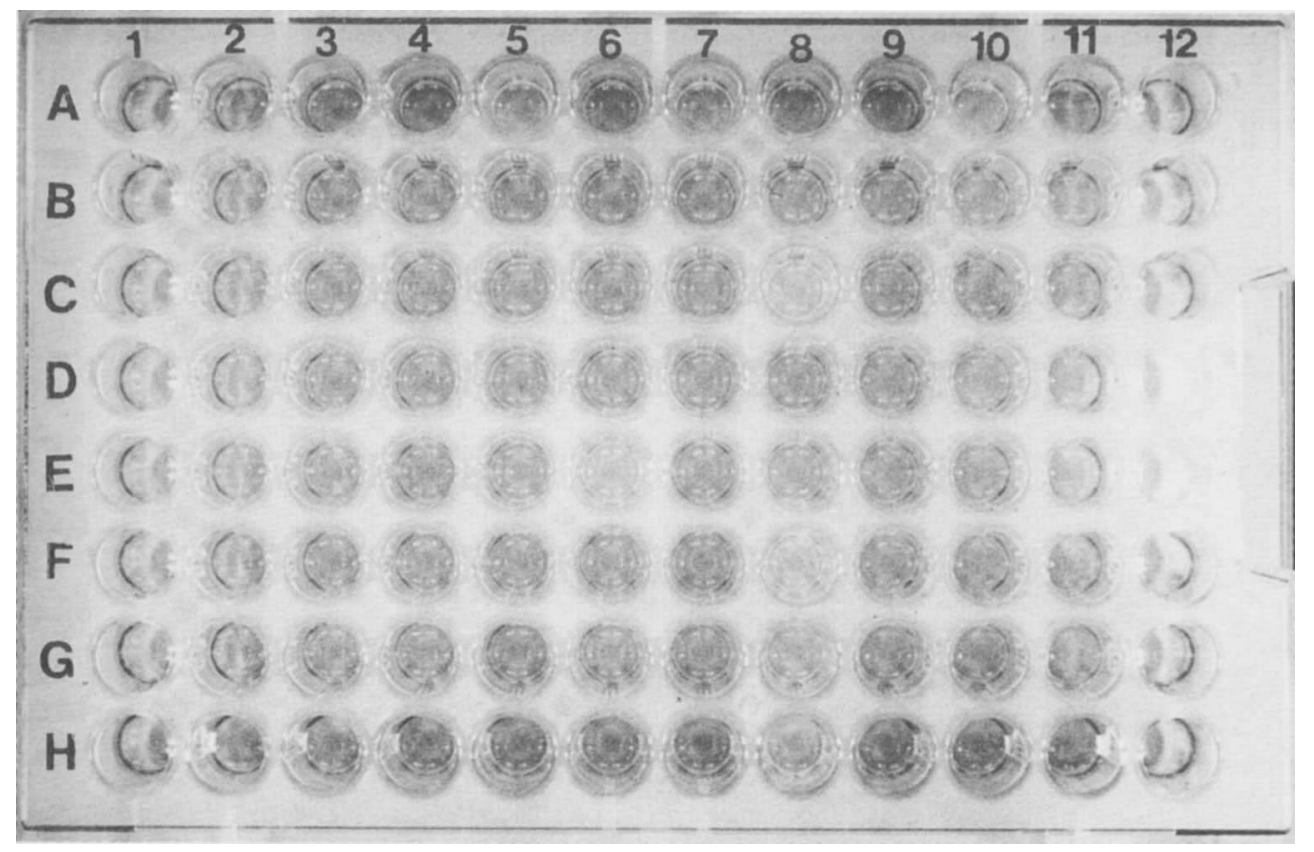

Fig. 1. Inhibition of adhesion of $H$. pylori to MKN45 cells by culture supernate of hybridoma cells according to urease activity of $H$. pylori. C8, E6 and F8 Wells exhibit no change in the colour of the medium indicating the inhibition of adhesion of $H$. pylori to MKN45 cells by MAb. 
Establishment of MAb A20 to inhibit adhesion of H. pylori to MKN45 cells

These 53 clones were investigated for their inhibitory effect on adhesion of $H$. pylori to MKN45 cells by flow cytometry. Only one MAb A20 was selected according to these criteria. MAb A20 was confirmed to be of the IgM class. The adhesion of $H$. pylori to MKN45 cells was inhibited after co-cultivation with MAb A20 (Fig. 2). After co-cultivation with MAb A20 $500 \mu \mathrm{g} / \mathrm{ml}$, the inhibition rate estimated by comparison with positive control cells was $50.6 \%$. None of the other 52 clones showed any inhibition of adhesion in flow cytometry.

A pretreatment experiment was performed to determine whether MAb A20 reacted with either H. pylori or MKN45 cells. Pretreatment of $H$. pylori with MAb A20 significantly inhibited its adhesion to MKN45 cells (Table 1). After pretreatment of $H$. pylori with $\mathrm{MAb} \quad \mathrm{A} 20 \quad 500 \mu \mathrm{g} / \mathrm{ml}$, the inhibition rate was estimated to be $74.4 \%$. On the other hand, pretreatment of MKN45 cells with MAb A20 did not inhibit adhesion of $H$. pylori to these MKN45 cells at all (data not shown).

Kato III and Int-407 cells were used to examine the inhibition of adhesion of $H$. pylori to other cells by MAb A20 (Table 2). After treatment of $H$. pylori with
Table 1. Inhibition of adhesion of $H$. pylori to MKN45 cells by MAb A20 in flow cytometry

\begin{tabular}{lcccc}
\hline & \multicolumn{4}{c}{ Fluorescence intensity* } \\
\cline { 2 - 5 } $\begin{array}{l}\text { Concentration of } \\
\text { MAb }(\mu \mathrm{g} / \mathrm{ml})\end{array}$ & Mean & SD & $\begin{array}{c}\text { Peak } \\
\text { channel }\end{array}$ & $\begin{array}{c}\text { Inhibition } \\
\text { rate }^{\dagger}\end{array}$ \\
\hline 500 & 89.5 & 66.6 & 119 & 74.4 \\
250 & 110.1 & 80.7 & 143 & 68.3 \\
125 & 146.5 & 106.9 & 164 & 58.1 \\
0 & 347.9 & 219.5 & 284 & - \\
\hline
\end{tabular}

${ }^{*} H$. pylori $\left(5 \times 10^{8} \mathrm{cfu}, \mathrm{PKH}-2\right.$ treated $)$ was pretreated with each concentration of MAb A20 and then incubated with MKN45 cells $\left(1 \times 10^{6}\right.$ cells $)$.

${ }^{\dagger} 100$ - (mean fluorescence of the sample with $\mathrm{MAb} /$ mean fluorescence of the sample without MAb) $\times 100$.

Table 2. Inhibition of adhesion of $H$. pylori to epithelial cells by MAb A20*

\begin{tabular}{lccc}
\hline Cell line & $\begin{array}{c}\text { Concentration of } \\
\text { MAb A20 } \\
(\mu \mathrm{g} / \mathrm{ml})\end{array}$ & $\begin{array}{c}\text { Mean } \\
\text { fluorescence } \\
\text { intensity }\end{array}$ & $\begin{array}{c}\text { Inhibition rate } \\
(\%)^{\dagger}\end{array}$ \\
\hline Kato III & 500 & 477.6 & 27.5 \\
Int-407 & 0 & 658.4 & - \\
& 500 & 264.8 & 0 \\
\hline
\end{tabular}

${ }^{*}$ H. pylori $\left(5 \times 10^{8} \mathrm{cfu}, \mathrm{PKH}-2\right.$ treated $)$ was pretreated with $\mathrm{MAb}$ A20 and then incubated with each cell line $\left(1 \times 10^{6}\right.$ cells $)$.

${ }^{\dagger} 100-$ (mean fluorescence of the sample with $\mathrm{MAb} /$ mean fluorescence of the sample without MAb) $\times 100$.

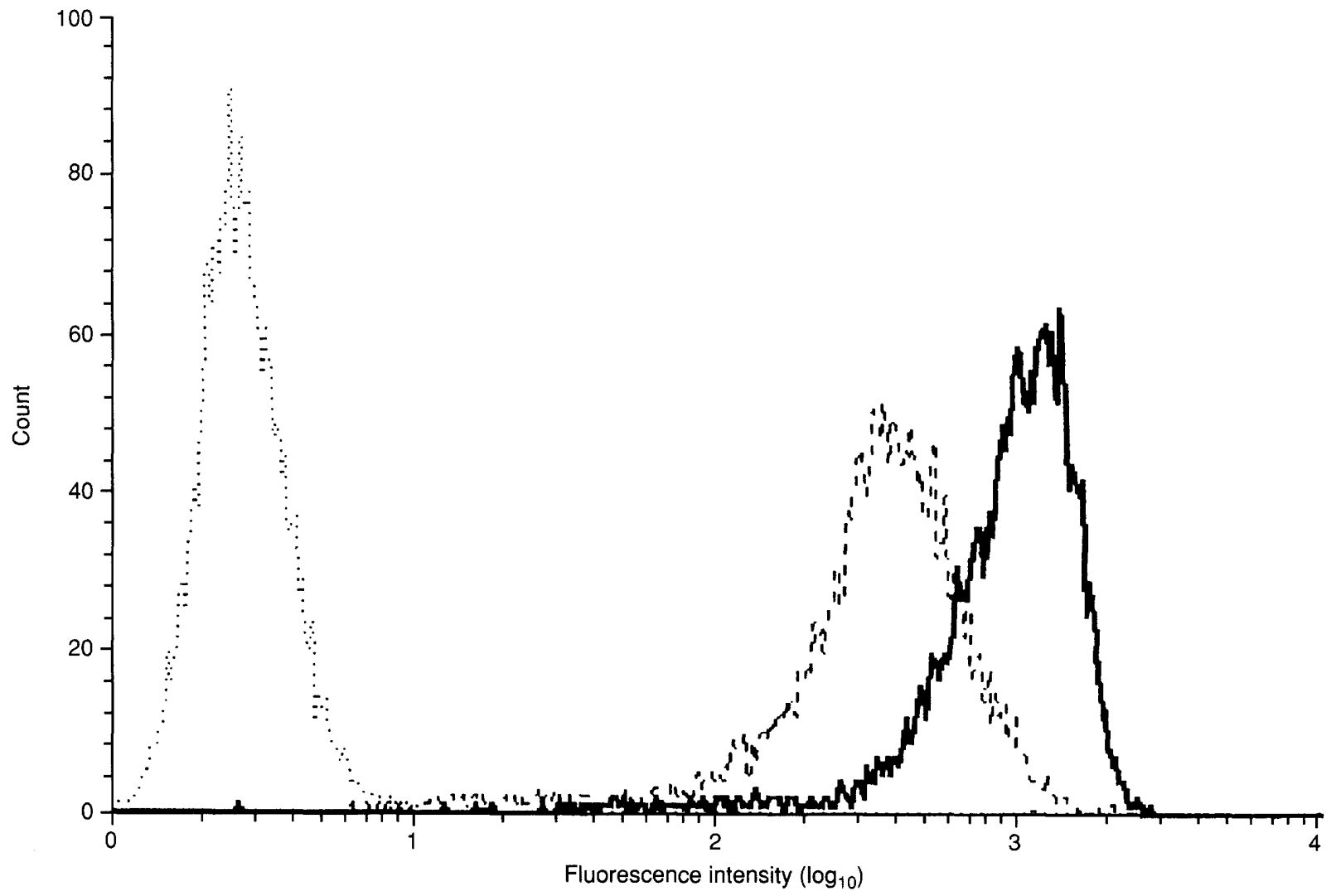

Fig. 2. Inhibition of adhesion of $H$. pylori to MKN45 cells by MAb A20 in flow cytometry: negative control MKN45 cells; __ , positive control, MKN45 cells were co-incubated with H. pylori strain TK1029; - - -, MKN45 cells were co-incubated with $H$. pylori strain TK1029 in the presence of MAb A20 $(500 \mu \mathrm{g} / \mathrm{ml})$. 
MAb A20 $500 \mu \mathrm{g} / \mathrm{ml}$, the inhibition of adhesion of $H$. pylori to Kato III cells was also demonstrated and the inhibition rate was $27.5 \%$. In contrast, MAb A20 did not inhibit the adhesion of $H$. pylori to Int-407 cells.

\section{Surface exposure of MAb-reactive antigens}

To confirm that MAb A20 recognises surface antigen of $H$. pylori, immuno-electron microscopy was performed. The MAb A20 bound to the cell surface of $H$. pylori strain TK1029, but not to cytoplasm (Fig. 3). The mean numbers of gold particles counted inside and outside of $H$. pylori were 101.7 SD 32.9 and 876.7 SD 62.3 , respectively (data not shown).

\section{Enzyme treatment and detection of glycochain}

To characterise the MAb A20-recognising antigen, immunoblot analysis after SDS-PAGE of whole $H$. pylori antigen with or without treatment with proteinase $\mathrm{K}$ was performed. MAb A20 reacted with a $35-\mathrm{kDa}$ antigen of the whole-cell lysate of $H$. pylori strain TK1029 (Fig. 4A). Treatment with proteinase $\mathrm{K}$ did not inhibit the reaction of MAb A20, although the same treatment inhibited completely the reaction of MAb H20, which recognises heat-shock protein 60 of $H$. pylori (data not shown). Glycochain was detected by the G-P sensor kit in the same size molecule recognised by MAb A20 (Fig. 4B).

\section{Reactivity of LPS of $H$. pylori with MAb A2O}

Immunoblot analysis and ELISA of purified LPS of $H$. pylori strains TK1029 and TK1028 were performed with MAb A20. The purified LPS of strains TK1029 and TK1028 were reactive with MAb A20 in immunoblot analysis (Fig. 5). In ELISA, it was also shown that the purified LPS reacted with MAb A20 (data not shown).

Specificity in the reaction of LPS with MAb A20

A total of 42 strains of $H$. pylori was tested by ELISA with MAb A20 (Table 3). MAb A20 reacted with 31 strains of $H$. pylori examined. The strains of $H$. pylori were separated into three groups according to their reactivity in ELISA. The adhesion of highly reactive strains $\left(\mathrm{OD}_{490}>1.0\right)$ of $\mathrm{H}$. pylori was inhibited after treatment with MAb A20. Correlation between the reactivity with MAb A20 in ELISA and inhibitory effect of MAb A20 on adhesion estimated by flow cytometry among H. pylori strains was statistically significant $(\mathrm{r}=0.7436)$.

MAb A20 had no reactivity in ELISA with other bacteria such as C. jejuni, E. coli, H. mustelae, $K$. pneumoniae, P. mirabilis, Ps. aeruginosa, S. marcescens, Sh. sonnei and V. cholerae (data not shown).

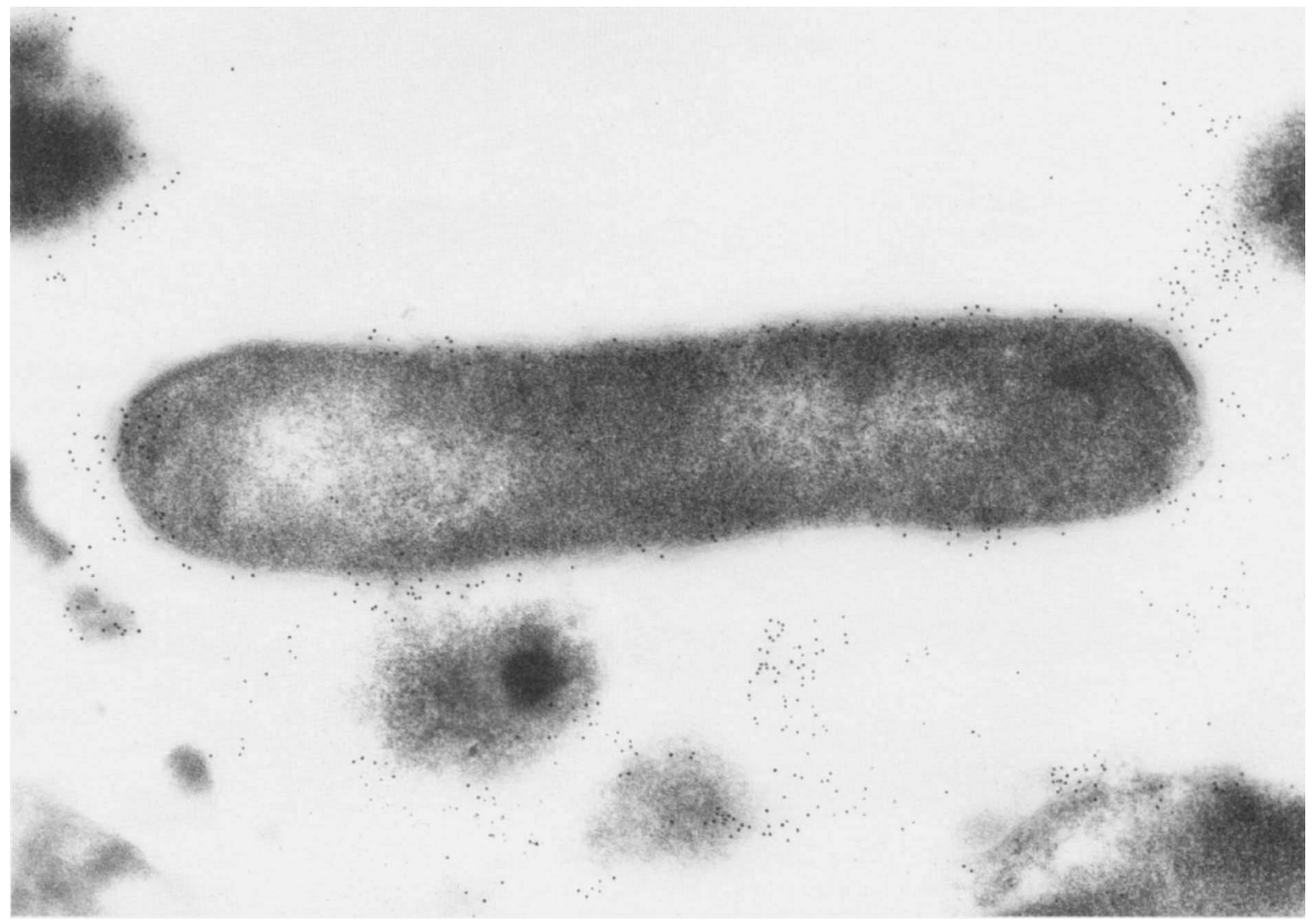

Fig. 3. Electron micrograph of $H$. pylori strain TK1029 incubated with MAb A20 with immunogold labelling $(\times 58000)$. Gold particles were mainly observed on the surface of $H$. pylori, but not in the cytoplasm. 
A

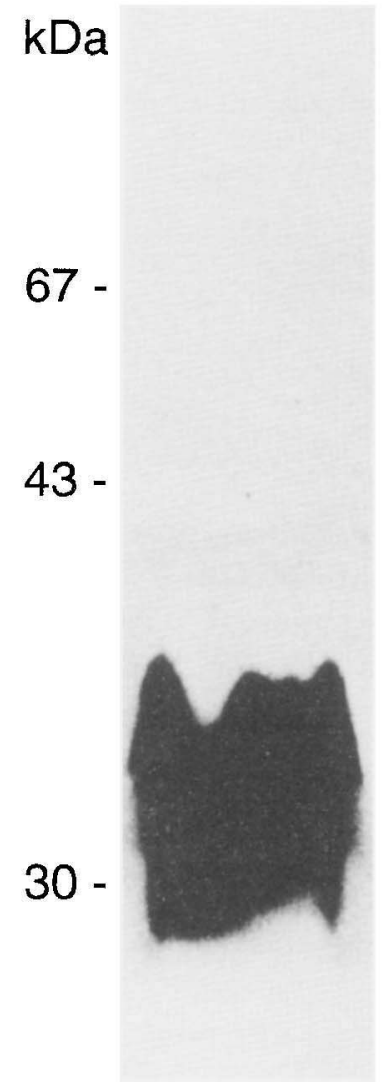

B

$\mathrm{kDa}$

$43-$

30

Fig. 4. Immunoblot analysis of $H$. pylori strain TK1029 with MAb A20 (A) and detection of glycochain (B) after SDS-PAGE of $H$. pylori strains.

Table 3. Reactivities of $H$. pylori strains with MAb A20 and inhibition of adhesion of $H$. pylori to MKN45 cells by MAb A20

\begin{tabular}{lcc}
\hline $\begin{array}{l}\text { ELISA value* } \\
\left(\mathrm{OD}_{490}\right)\end{array}$ & $\begin{array}{c}\text { Number of strains } \\
\text { examined }\end{array}$ & $\begin{array}{c}\text { Number of inhibition- } \\
\text { positive strains }\end{array}$ \\
\hline$>1.0$ & 16 & 16 \\
$0.1-1.0$ & 15 & 2 \\
$<0.1$ & 11 & 0 \\
\hline
\end{tabular}

${ }^{*}$ Microtitration plate was coated with $2500 \mathrm{ng}$ of whole-cell lysate of H. pylori/well.

${ }^{\dagger} H$. pylori $\left(5 \times 10^{8} \mathrm{cfu}\right)$ were incubated with $1 \times 10^{6} \mathrm{MKN} 45$ cells at $37^{\circ} \mathrm{C}$ for $1 \mathrm{~h}$ with MAb A20 $(250 \mu \mathrm{g} / \mathrm{ml})$. Positive control was incubated without MAb A20.

\section{Discussion}

The study established MAb A20, as an inhibitor of adhesion of $H$. pylori to MKN45 cells (Figs. 1-3). Pretreatment of $H$. pylori with MAb A20 inhibited the adhesion of $H$. pylori to MKN45 cells, depending on the concentration of the MAb (Table 1), but pretreatment of MKN45 cells with the MAb did not inhibit adhesion of $H$. pylori at all. These data show that the

A 1

$\mathrm{kDa}$

$67-$

$43-$

$30-$

20

Fig. 5. SDS-PAGE and immunoblot analysis of purified LPS of $H$. pylori strains with MAb A20 (A) SDS-PAGE of LPS of strains TK1029 (lane 1) and TK1028 (2) followed by staining with silver reagent kit; (B) immunoblot analysis after SDS-PAGE of LPS of strains TK1029 (lane 1) and TK1028 (2) with MAb A20.

MAb blocked bacterial substances involved in the adhesion system. After pretreatment with MAb A20 $500 \mu \mathrm{g} / \mathrm{ml}$, the inhibition effect was incomplete and the inhibition rate estimated by comparison with positive control cells was $74.4 \%$. Even when lower numbers of $H$. pylori $\left(c .5 \times 10^{6}\right)$ were used for the adhesion assay, the inhibition of adhesion by MAb A20 was still only partial (data not shown). It is possible that several receptor-ligand interactions are involved in $H$. pylori adhesion to gastric epithelial cells.

A previous study compared the adhesion of $H$. pylori to MKN45, Kato III, Int-407 and MKN28 cells [23]. It was shown that cell line MKN45 is the most sensitive for adhesion of $H$. pylori and Int-407 is the least sensitive. In the present study, it was observed that adhesion of $\mathrm{H}$. pylori to Int-407 cells was not inhibited by MAb A20. These results suggest that Int407 cells have a different type of adhesion receptor to MKN45 and Kato III cells.

It was shown that the adhesion of $H$. pylori to MKN45 cells could be inhibited by MAb A20 recognising the bacterial surface antigen, LPS. 
Furthermore, purified LPS of $H$. pylori strain TK1029 bound to MKN45 cells. This result indicates that LPS is also an important factor for adhesion of $H$. pylori to MKN45 cells. The role of LPS in adherence to host cells has been reported recently. Valkonen et al. [30] showed that initial recognition and binding of laminin by $H$. pylori may occur through LPS. A similar adhesion mechanism involving LPS and protein receptors on epithelial cells has been described for C. jejuni [31], Sh. flexneri [32], Actinobacillus pleuropneumoniae [33], E. coli [34], Pasteurella multocida [35], and Ps. aeruginosa [36]. These LPSs show inhibition of adhesion of these bacteria to various host cells. LPS of $H$. pylori can inhibit the interaction between laminin and its receptor on epithelial cells [37], but LPS has received only limited attention as a potential tissue adhesin [38]. However, LPS is a surface antigen of $H$. pylori, and anti-LPS MAb A20 may be able to agglutinate bacteria. This is likely to result in decreased adhesion. It is also possible that MAb A20 masks another surface adhesin and blocks adhesion of $H$. pylori.

MAb A20 had different reactivity to $H$. pylori strains tested in ELISA, suggesting antigenic variety of $H$. pylori in terms of LPS expression. Moran et al. [38] found structural or substitutional differences, or both, in the core composition of the rough LPS of various strains. Doig and Trust [39] also reported that two MAbs, recognising the core region of LPS and the flagella sheath of $H$. pylori, were strain-specifically reactable.

The biological activities of LPS of $H$. pylori have been compared with activities of LPS of Enterobacteriaceae. Mitogenicity in mouse spleen cells, pyrogenicity in rabbits, lethal toxicity in galactosaminesensitised mice and macrophage activation of LPS of $H$. pylori were demonstrated, but its activity was lower that that of Enterobacteriaceae [40, 41]. Generally, LPS is an immunodominant substance and anti-LPS MAb-producing hybridoma is found with high frequency. In the present study, almost 900 hybridoma cells were assayed and only one, MAb A20, was selected.

It has recently been reported that MAbs specific for Lewis blood group antigen $\left(\mathrm{Le}^{\mathrm{X}}\right.$ and $\mathrm{Le}^{\mathrm{Y}}$ ) reacted with LPS of $H$. pylori strains in immuno-electron microscopy and ELISA, and that the MAbs specific for $H$. pylori LPS reacted with purified Lewis antigens $[42,43]$. These data show that $H$. pylori expresses a complex surface carbohydrate corresponding to Lewis blood group antigens in LPS. In the preliminary study, the MAb specific for $\mathrm{Le}^{\mathrm{X}}$ reacted with the antigen which MAb A20 recognised from whole-cell lysate of strain TK1029 in immunoblot analysis (data not shown). Whether the MAb A20 blocks the core Oantigenic chain or another component of LPS as terminal Lewis antigen remains to be demonstrated.
This research was supported by Grants-in-Aid for Scientific Research from the Ministry of Education, Science and Culture.

\section{References}

1. Graham DY. Campylobacter pylori and peptic ulcer disease Gastroenterology 1989; 96: 615-625.

2. Marshall BJ, Warren JR. Unidentified curved bacilli in the stomach of patients with gastritis and peptic ulceration. Lancet 1984; 1: $1311-1315$.

3. Nomura A, Stemmermann GN, Chyou P-H, Kato I, Perez-Perez GI, Blaser MJ. Helicobacter pylori infection and gastric carcinoma among Japanese Americans in Hawaii. $N$ Engl $J$ Med 1991; 325: 1132-1136.

4. Parsonnet J, Hansen S, Rodriguez L et al. Helicobacter pylori infection and gastric lymphoma. $N$ Engl $J$ Med 1994; 330: $1267-1271$

5. Hazell SL, Lee A, Brady L, Hennessy W. Campylobacter pyloridis and gastritis: association with intracellular spaces and adaptation to an environment of mucus as important factors in colonization of the gastric epithelium. J Infect Dis 1986; 153 658-663.

6. Jacques M. Role of lipo-oligosaccharides and lipopolysaccharides in bacterial adhesion. Trends Microbiol 1996; 4: 408-409.

7. Evans DG, Evans DJ, Graham DY. Receptor-mediated adherence of Campylobacter pylori to mouse Y-1 adrenal cell monolayers. Infect Immun 1989; 57: 2272-2278.

8. Falk P, Roth KA, Borén T, Westblom TU, Gordon JI, Normark $\mathrm{S}$. An in vitro adherence assay reveals that Helicobacter pylori exhibits cell lineage-specific tropism in the human gastric epithelium. Proc Natl Acad Sci USA 1993; 90: 2035-2039.

9. Fauchere JL, Blaser MJ. Adherence of Helicobacter pylori cells and their surface components to HeLa cell membranes. Microb Pathog 1990; 9: 427-439.

10. Hemalatha SG, Drumm B, Sherman P. Adherence of Helicobacter pylori to human gastric epithelial cells in vitro. $\mathrm{J} \mathrm{Med}$ Microbiol 1991; 35: 197-202.

11. Evans DG, Evans DJ, Moulds JJ, Graham DY. N-Acetylneuraminyllactose-binding fibrillar hemagglutinin of Campylobacter pylori: a putative colonization factor antigen. Infect Immun 1988; 56: 2896-2906.

12. Lelwala-Guruge J, Ljungh $\AA$, Wadström T. Haemagglutination patterns of Helicobacter pylori: frequency of sialic acidspecific and non-sialic acid-specific haemagglutinins. APMIS 1992; 100: $908-913$.

13. Nakazawa T, Ishibashi M, Konishi $H$, Takemoto T, Sigeeda M, Kochiyama T. Hemagglutination activity of Campylobacter pylori. Infect Immun 1989; 57: 989-991.

14. Saitoh T, Natomi H, Zhao W et al. Identification of glycolipid receptors for Helicobacter pylori by TLC-immunostaining. FEBS Lett 1991; 282: 385-387.

15. Slomiany BL, Piotrowski J, Samanta A, VanHorn K, Murty VLN, Slomiany A. Campylobactor pylori colonization factor shows specificity for lactosylceramide sulfate and GM3 ganglioside. Biochem Int 1989; 19: 929-936.

16. Moran AP, Kuusela P, Kosunen TU. Interaction of Helicobacter pylori with extracellular matrix proteins. $J$ Appl Bacteriol 1993; 75: $184-189$.

17. Trust TJ, Doig P, Emödy L, Kienle Z, Wadström T, O'Toole P. High-affinity binding of the basement membrane proteins collagen type IV and laminin to the gastric pathogen Helicobacter pylori. Infect Immun 1991; 59: 4398-4404.

18. Lingwood CA, Huesca M, Kuksis A. The glycolipid receptor for Helicobacter pylori (and exoenzyme S) is phosphatidylethanolamine. Infect Immun 1992; 60: 2470-2474.

19. Lingwood CA, Law H, Pellizzari A, Sherman P, Drumm B. Gastric glycerolipid as a receptor for Campylobacter pylori. Lancet 1989; 2: 283-241.

20. Borén T, Falk P, Roth KA, Larson G, Normark S. Attachment of Helicobacter pylori to human gastric epithelium mediated by blood group antigens. Science 1993; 262: 1892-1895.

21. Clyne M, Drumm B. Adherence of Helicobacter pylori to primary human gastrointestinal cells. Infect Immun 1993; 61: $4051-4057$

22. Yamamoto-Osaki T, Yamaguchi H, Taguchi H, Ogata S, Kamiya S. Adherence of Helicobacter pylori to cultured 
human gastric carcinoma cells. Eur $J$ Gastoenterol Hepatol 1995; 7(Suppl1): 5871-1592.

23. Osaki T, Yamaguchi H, Taguchi H, Kumada J, Ogata S, Kamiya S. Studies on the relationship between adherence activity and haemagglutination by Helicobacter pylori. $\mathrm{J} \mathrm{Med}$ Microbiol 1997 46: 117-121.

24. Taguchi H, Osaki T, Yamaguchi H, Kamiya S. Flow cytometric analysis using lipophilic dye PKH-2 for adhesion of Vibrio cholerae to intestine 407 cells. Microbiol Immunol 1995; 39: 891-894.

25. Yamaguchi $\mathrm{H}$, Yamamoto $\mathrm{T}$, Taguchi $\mathrm{H}$, Ogata S. Yersinia enterocolitica immunodominant $60 \mathrm{kDa}$ antigen, common to a broad range of bacteria, is a heat-shock protein. $J$ Gen Microbiol 1990; 136: 1091-1097.

26. Negrini R, Lisato L, Cavazzini L et al. Monoclonal antibodies for specific immunoperoxidase detection of Campylobacter pylori. Gastroenterology 1989; 96: 414-420.

27. Taguchi $\mathrm{H}$, Yamaguchi $\mathrm{H}$, Yamamoto $\mathrm{T}$, Kamiya S. Immunocytochemical localization of $60-\mathrm{kDa}$ heat shock protein in Vibrio cholerae. Zentralbl Bakteriol 1996; 284: 496-500.

28. Laemmli UK. Cleavage of structural proteins during the assembly of the head of bacteriophage T4. Nature 1970; 227: 680-685.

29. Westphal O, Lüderits O, Bister F. Über die extraktion von bakterien mit phenol/wasser. A Naturforsch Teil B 1952; 7: $148-155$.

30. Valkonen KH, Wadström $\mathrm{T}$, Moran AP. Interaction of lipopolysaccharides of Helicobacter pylori with basement membrane protein laminin. Infect Immun 1994; 62: 3640-3648.

31. McSweegan E, Walker RI. Indentification and characterization of two Campylobacter jejuni adhesions for cellular and mucous substrates. Infect Immun 1986; 53: 141-148.

32. Izhar M, Nuchamowitz Y, Mirelman D. Adherence of Shigella flexneri to guinea pig intestinal cells is mediated by a mucosal adhesion. Infect Immun 1982; 35: 1110-1118.

33. Bélanger M, Dubreuil D, Harel J, Girard C, Jacques M. Role of lipopolysaccharides in adherence of Actinobacillus pleuropneu- moniae to porcine tracheal rings. Infect Immun 1990; 58: 3523-3530.

34. Cohen PS, Arruda JC, Williams TJ, Laux DC. Adhesion of a human fecal Escherichia coli strain to mouse colonic mucus. Infect Immun 1985; 48: 139-145.

35. Jacques $M$, Kobisch $M$, Bélanger M, Dugal F. Virulence of capsulated and noncapsulated isolates of Pasteurella multocida and their adherence to porcine respiratory tract cells and mucus. Infect Immun 1993; 61: 4785-4792.

36. Pier GB, Grout M, Zaidi TS et al. Role of mutant CFTR in hypersusceptibility of cystic fibrosis patients to lung infections. Science 1996; 271: 64-67.

37. Slomiany BL, Piotrowski J, Rajiah G, Slomiany A. Inhibition of gastric mucosal laminin receptor by Helicobacter pylori lipopolysaccharide: effect of nitecapone. Gen Pharmacol 1991; 22: $1063-1069$

38. Moran AP, Helander IM, Kosunen TU. Compositional analysis of Helicobacter pylori rough-form lipopolysaccharides. $J$ Bacteriol 1992; 174: 1370-1377.

39. Doig P, Trust TJ. Identification of surface-exposed outer membrane antigens of Helicobacter pylori. Infect Immun 1994; 62: 4526-4533.

40. Muotiala A, Helander IM, Pyhälä L, Kosunen TU Moran AP Low biological activity of Helicobacter pylori lipopolysaccharide. Infect Immun 1992; 60: 1714-1716.

41. Përez-Përez GI, Shepherd VL, Morrow JD, Blazer MJ. Activation of human THP-1 cells and rat bone marrow-derived macrophages by Helicobacter pylori lipopolysaccharide. Infect Immun 1995; 63: 1183-1187.

42. Applemelk BJ, Simoons-Smit I, Negrini R et al. Potential role of molecular mimicry between Helicobacter pylori lipopolysaccharide and host Lewis blood group antigens in autoimmunity. Infect Immun 1996; 64: 2031-2040.

43. Sherburne R, Taylor DE. Helicobacter pylori expresses a complex surface carbohydrate, Lewis X. Infect Immun 1995; 63: $4564-4568$. 